\title{
Manajemen Anestesi Subarachnoid Block pada Pasien dengan Impending Eklampsia
}

\section{RTH Soepraptomo}

Departemen Anestesiologi dan Terapi Intensif, Fakultas Kedokteran Universitas Sebelas Maret/RS Dr. Moewardi Surakarta

\begin{abstract}
Abstrak
Pendahuluan: Impending eclampsia merupakan masalah yang serius dalam kehamilan karena komplikasikomplikasi yang dapat timbul baik pada ibu maupun pada janin. Salah satu cara terbaik untuk meningkatkan keselamatan ibu dan bayi pada pasien dengan impending eklampsia adalah dengan dilakukan pembedahan caesar. Laporan Kasus: Pada kasus ini, akan dibahas lebih lanjut terkait wanita 39 tahun dengan G4P3A0 hamil 39 minggu dengan impending eclampsia. Pasien ini memiliki status fisik ASA III-E dan dilakukan tindakan sectio caesarea transperitoneal emergency dengan teknik anestesi regional subarachnoid block. Bayi lahir berjenis kelamin perempuan dengan APGAR score 7-8-9. Diskusi: Anestesi regional subarachnoid block dipilih karena mempunyai banyak keuntungan seperti kesederhanaan teknik, onset yang cepat, resiko keracunan sistemik yang kecil, blok anestesi yang baik, pencegahan perubahan fisiologi dan penanggulangannya sudah diketahui dengan baik. Kesimpulan: Diagnosis dan manajemen yang tepat pada ibu hamil dengan impending eclampsia sangat penting untuk kelangsungan hidup pasien. Pemilihan jenis anestesi subarachnoid block dipilih sesuai dengan kondisi klinis pasien dengan memperhitungkan segala aspek keuntungan, kerugian dan aspek medis lainnya.
\end{abstract}

Kata kunci: impending eclampsia; regional subarachnoid block; sectio caesarea transpertoneal

\section{Management Anesthesia Subarachnoid Block for Patient with Impending Eclampsia}

\begin{abstract}
Introduction: Impending eclampsia is a serious problem in pregnancy because of complications that can arise both for the mother and the fetus. One way to speed up handling and improve the safety of mother and baby in patients with impending eclampsia is by caesarean section. Case Report: In this case, we will discuss about 39-yearold woman with G4P3A0 39 weeks pregnancy with impending eclampsia. This patient has ASA III-E physical status and performed transperitoneal emergency sectio caesarea under regional subarachnoid block anesthesia. The baby is female, born alive without abnormalities and has 7-8-9 APGAR score. Discussion: Regional subarachnoid block anesthesia was chosen because it has many advantages such as simple technic, rapid onset, a small risk of systemic poisoning, good anesthesia block, prevention of physiological changes, and its handling are well known. Conclusion: Proper diagnosis and management of pregnant women with impending eclampsia is very important for patient survival. The choice of subarachnoid block anesthesia is chosen according to the clinical condition of the patient by considering all aspects of the advantages, disadvantages, and other medical aspects.
\end{abstract}

Key words: impending eclampsia; regional subarachnoid block; sectio caesarea transpertoneal 


\section{Pendahuluan}

Tiga penyebab utama kematian ibu dalam bidang obstetri adalah: pendarahan 45\%, infeksi 15\%, dan preeklampsia $13 \%$. Sisanya terbagi atas partus macet, abortus yang tidak aman, dan penyebab tidak langsung lainnya. Dalam perjalanannya, berkat kemajuan dalam bidang anestesia, teknik operasi, pemberian cairan infus dan transfusi, dan peranan antibiotik yang semakin meningkat, maka penyebab kematian ibu karena pendarahan dan infeksi dapat diturunkan secara nyata. Sebaliknya pada penderita preeklampsia, karena ketidaktahuan dan sering terlambat mencari pertolongan setelah gejala klinis berkembang menjadi preeklampsia berat dengan segala komplikasinya, angka kematian ibu bersalin belum dapat diturunkan. ${ }^{1,2}$

Impending eklampsia merupakan masalah yang serius dalam kehamilan karena komplikasikomplikasi yang dapat timbul baik pada ibu maupun pada janin. Komplikasi pada ibu antara lain gagal ginjal akibat nekrosis tubuler akut, nekrosis kortikal akut, gagal jantung, edema paru, trombositopenia, DIC, dan cerebrovascular accident. Sedangkan komplikasi pada janin antara lain prematuritas ekstrem, intrauterine growth retardation (IUGR), abruptio plasenta, dan asfiksia perinatal. Oleh karena itu dibutuhkan penanganan secara cepat dan tepat apabila dijumpai kasus kehamilan dengan impending eklampsia., ${ }^{3,4}$ Salah satu cara untuk mempercepat penanganan dan meningkatkan keselamatan ibu dan bayi pada pasien dengan impending eklampsia adalah dengan dilakukan pembedahan caesar. ${ }^{5}$ Mengingat besarnya risiko yang dihadapi maka operasi caesar merupakan alternatif pilihan terbaik bagi pasien. Teknik anestesi yang dapat digunakan untuk section caesaria adalah anestesi spinal, anestesi epidural dan anestesi umum. Pemilihan jenis anestesi yang akan digunakan disesuaikan dengan masing- masing kondisi pasien. $^{5,6}$

\section{Kasus}

Anamnesis

Pada tanggal 21 April 2019, datang seorang wanita G2P1A0 usia 39 tahun dengan umur kehamilan 35+1 minggu datang rujukan dari RSUD Bagas Waras Klaten dengan keterangan G4P3A0, usia kehamilan 35 minggu BDP AH 1, PEB, HT grade II. Pasien merasa hamil 8 bulan lebih, gerakan janin masih dirasakan, kencengkenceng teratur belum dirasakan, air kawah belum dirasakan. Pasien mengeluh nyeri kepala depan $(+)$, pandangan kabur $(+)$, nyeri ulu hati $(-)$, mual (+), muntah (-), lendir darah (-). Pasien menyatakan tensi pasien meningkat sejak usia kehamilan 32 minggu. Pasien memiliki tekanan darah tinggi sejak hamil anak ke 2 (preeklampsia). Pasien melakukan ANC sebanyak 2 kali di dokter spesialis kandungan dan setiap bulan di PKU Wedi.

\section{Pemeriksaan Fisik}

Kondisi pasien sadar penuh, GCS E4V5M6. Pasien memiliki tekanan darah 200/129 mmHg, nadi $82 \mathrm{x} /$ menit, laju respirasi $18 \mathrm{x} /$ menit, suhu $36,6{ }^{\circ} \mathrm{C}$, dan saturasi oksigen 99\%. Airway pasien clear dengan kemampuan buka mulut $3 \mathrm{~cm}$, TMD $6 \mathrm{~cm}$, mallampati II, trakea di tengah. Pada pemeriksaan thorax ditemukan bentuk normochest, simetris, pengembangan dada kanan=kiri, retraksi (-/-), otot bantu nafas (-/-), sonor/sonor, suara dasar vesikuler $(+/+)$, suara tambahan (-/-). Pada pemeriksaan jantung BJ1-2 tunggal, irama reguler, murmur (-). Pada pemeriksaan abdomen gerak peristaltik $(+)$ dalam batas normal, gravid, DJJ 145x/menit regular, TFU 28cm 2015 gram, kepala janin belum masuk panggul. Akral hangat, oedema di seluruh ekstremitas.

\section{Laboratorium Darah}

Hasil pemeriksaan laboratorium darah dapat dilihat pada tabel 1. Hasil laboratorium darah menunjukkan adanya leukositosis, hipoalbuminemia, serta proteinuria berat. Dari hasil pemeriksaan USG didapatkan kesan janin tampak baik. Hasil pemeriksaan CTG menunjukkan NST kategori I (baseline 145 bpm, variabilitas 5-10, akselerasi (-), deselerasi (-), kontraksi (-), fetal movement $(+)$.

\section{Pengelolaan Anestesi}

Oleh karena pasien memiliki tekanan darah 
Tabel 1. Hasil Pemeriksaan Laboratorium Darah

\begin{tabular}{llll}
\hline Pemeriksaan & Hasil & Satuan & Rujukan \\
\hline $\mathrm{Hb}$ & 12.1 & $\mathrm{~g} / \mathrm{dl}$ & $12.0-15.6$ \\
$\mathrm{HCT}$ & 36 & $\%$ & $33-45$ \\
$\mathrm{RBC}$ & 4.20 & $10^{6} / \mu \mathrm{l}$ & $4.10-5.10$ \\
$\mathrm{WBC}$ & 13.4 & $10^{3} / \mu \mathrm{l}$ & $4,5-11$ \\
$\mathrm{AT}$ & 263 & $10^{3} / \mu \mathrm{l}$ & $150-450$ \\
$\mathrm{GDS}$ & 102 & $\mathrm{mg} / \mathrm{dL}$ & $60-140$ \\
$\mathrm{PT}$ & 11.1 & Detik & $10.0-15.0$ \\
$\mathrm{APTT}$ & 26.9 & Detik & $20.0-40.0$ \\
$\mathrm{INR}$ & 0.820 & & \\
$\mathrm{SGOT}$ & 24 & $\mathrm{U} / \mathrm{L}$ & $<31$ \\
SGPT & 12 & $\mathrm{U} / \mathrm{L}$ & $<34$ \\
Albumin & 3.0 & $\mathrm{~g} / \mathrm{dL}$ & $3.2-4.5$ \\
Ureum & 22 & $\mathrm{mg} / \mathrm{dL}$ & $<50$ \\
Kreatinin & 0.6 & $\mathrm{mg} / \mathrm{dL}$ & $0.5-1.1$ \\
Na & 134 & $\mathrm{mmol} / \mathrm{L}$ & $132-145$ \\
$\mathrm{~K}$ & 3.8 & $\mathrm{mmol} / \mathrm{L}$ & $3.3-5.1$ \\
LDH & 300 & & \\
HbsAg & Nonreaktif & & Nonreaktif \\
Protein Kualitatif & +++ & & - \\
\hline
\end{tabular}

200/129 $\mathrm{mmHg}$ dan proteinuria +3 , pasien diberikan tatalaksana awal pre-eklamsi berat yaitu MgSO4 20\% 4 gram SP (inisial) di lanjutkan MgSO4 20\% 1 gr/jam dalam 24 jam dan Nifedipin $10 \mathrm{mg}$ per oral oleh TS Obsgin. Berdasarkan kondisi pasien, diagnosis anestesi sebagai berikut: wanita 39 tahun dengan G4P3A0 UK 39 minggu dengan impending eklampsia, pro SCTP emergensi, dengan status fisik ASA III E, plan RA-SAB. Saran tindakan dari anestesi adalah informed consent risiko tinggi, pasang IV line, puasa diteruskan, post operasi rawat di HCU.

Selanjutnya pasien dilakukan persiapan operasi antara lain, keluarga diberi penjelasan tentang rencana yang akan dilakukan, prosedur tindakan anestesi dan operasi, kemungkinan hal-hal yang bisa terjadi selama tindakan dan alternatif tindakan menghadapi resiko operasi, pemasangan infus jalur besar dengan IV line $18 \mathrm{G}$, persiapan obat

Tabel 2. Balance Cairan Durante Operasi

\begin{tabular}{|r|c|c|c|c|c|c|c|c|c|}
\hline & & \multicolumn{3}{|c|}{ Input } & \multicolumn{3}{c|}{ Output } & Balance \\
\hline & Jam & Kris & Kol & Drh & Drh & Urin & SO+M & \\
\hline $\begin{array}{c}07.45 \\
-\end{array}$ & 500 & - & - & 300 & 100 & 540 & -440 \\
\hline \begin{tabular}{c}
08.45 \\
\hline $\begin{array}{c}08.45 \\
-\end{array}$
\end{tabular} & 250 & - & - & 150 & 50 & 270 & -220 \\
\hline 09.15 & & & & & & & \\
\hline
\end{tabular}




\section{Grafik Hemodinamik Durante Operasi}

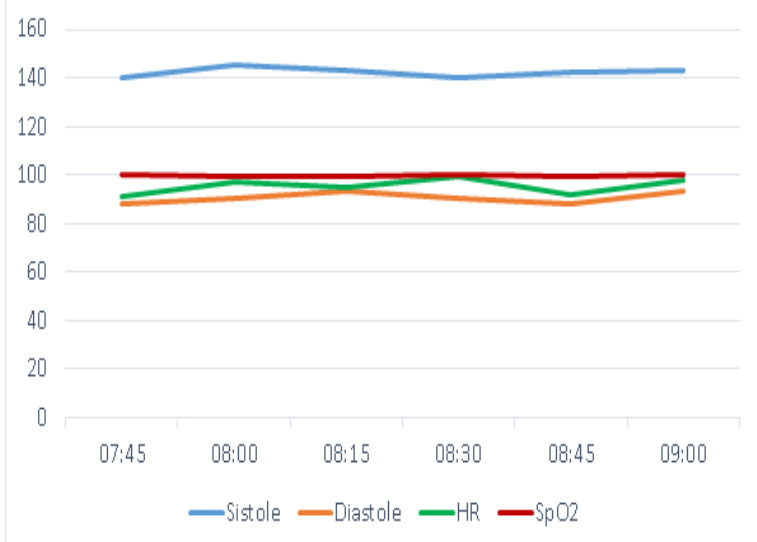

dan alat, komunikasi dengan TS Obsgin tentang tindakan yang akan dilakukan, maintenance MgSO4 tetap dijalankan 1 gram / jam IV.

Anestesi dimulai pukul 07.45 berlangsung 90 menit, sampai pukul 09.15. Tindakan bedah dilakukan mulai pukul 08.00-09.00 WIB. Dilakukan regional anestesi sub arachnoid block dengan spinal Lidodec $75 \mathrm{mg}$ dan fentany $125 \mathrm{mcg}$ secara intratekal. Setelah menunggu beberapa saat, perlahan pasien teranestesi. Kemudian dilakukan tindakan Sectio Caesaria dengan posisi supine pada pasien. Durante operasi diberikan $\mathrm{O}_{2}$ 3 lpm dengan nasal kanul dan infus Ringer laktat. Diberikan juga oksitosin 10 IU dan Parasetamol 1 gr per 8 jam. Kondisi pasien saat maintenance anestesi adalah sebagai berikut: 1) suara nafas vesikuler, nafas terkontrol, 2) perdarahan \pm 100 cc, 3) pupil isokor, 4) kateter terpasang, urin 100 cc, 5) bising usus (-), 6) tulang intak. Pemberian cairan selama operasi dilakukan dengan memerhatikan tiga faktor yaitu pemeliharaan, stres operasi, dan pengganti puasa, sehingga pemberian cairan saat operasi adalah sebanyak $90 \mathrm{ml}$. Tabel keseimbangan cairan dijelaskan melalui tabel keseimbangan cairan (lihat tabel 2).

Perhitungan kebutuhan transfusi pasien adalah sebagai berikut, EBV pasien $=90 \mathrm{cc} / \mathrm{kgBB}$ x $75 \mathrm{~kg}=6750 \mathrm{cc}$ Kebutuhan cairan selama operasi: maintenance $=90 \mathrm{cc} / \mathrm{jam}$, stres operasi $=6 \mathrm{cc} / \mathrm{kgBB} / \mathrm{jam} \times 75 \mathrm{~kg}=450 \mathrm{cc} / \mathrm{jam}$. Maka, kebutuhan cairan jam $\mathrm{I}=90 \mathrm{cc}+450 \mathrm{cc}=540 \mathrm{cc} /$ jam. Perdarahan yang terjadi selama operasi tidak mencapai ABL sehingga tidak perlu transfusi. Kondisi hemodinamik pasien dijelaskan dalam gambar 1.

\section{Pengelolaan Pascabedah}

Setelah operasi, pasien dirawat di HCU melati 1 untuk mendapat perawatan lebih lanjut. Keadaan umum pasien baik, kesadaran compos mentis, tekanan darah 140/80 mmHg, nadi $90 \mathrm{x} /$ menit, frekuensi napas $20 \mathrm{x} /$ menit. Tatalaksana post operasi meliputi 1) pengawasan KUVS dan tanda perdarahan, 2) puasa hingga bising usus $(+), 3$ ) fentanyl $0.5 \mathrm{mcg} / \mathrm{kgbb} / \mathrm{jam}, 150 \mathrm{mcg}$ dalam 500 cc habis dalam 3 jam. 4) parasetamol 1 gr/8jam, 5) protap PEB (Oksigen 3 lpm, IVFD RL 12 tpm, Injeksi $\mathrm{MgSO} 4$ 20\% 1 gram/jam selama 24 jam dan Nifedipine $3 \times 10 \mathrm{mg}$ jika tekanan darah $\geq$ 160/110 mmHg), inj. Ketorolac $30 \mathrm{mg} / 8$ jam, vit C $2 \times 50 \mathrm{mg}$

\section{Pembahasan}

Prinsip tatalaksana dari impending eklampsia adalah penanganan aktif yaitu terminasi kehamilan se-aterm mungkin, kecuali apabila ditemukan penyulit dapat dilakukan terminasi tanpa memandang usia kehamilan. Kemudian pada pasien dilakukan terminasi kehamilan dengan sectio caesaria emergensi atas indikasi maternal. Indikasi maternal adalah untuk mencegah timbulnya komplikasi eklampsia. Usia kehamilan pada kasus ini adalah kehamilan preterm. ${ }^{7,8}$

Pada tindakan-tindakan bedah sesar umumnya dipilih anestesi regional sub arachnoid block/ spinal karena mempunyai banyak keuntungan seperti kesederhanaan teknik, onset yang cepat, resiko keracunan sistemik yang kecil, blok anestesi yang baik, pencegahan perubahan fisiologi dan penanggulangannya sudah diketahui dengan baik, analgesia dapat diandalkan, sterilitas dijamin, pengaruh terhadap bayi sangat minimal, dapat mengurangi kemungkinan terjadinya aspirasi, dan ibu dapat kontak langsung dengan bayinya segera setelah melahirkan. Tetapi anestesi spinal juga bukan tanpa risiko, risiko yang dapat terjadi seperti mual dan muntah bisa terjadi pada anestesi spinal. Bradikardi, 
disritmia atau bahkan cardiac arrest merupakan komplikasi yang bisa terjadi. ${ }^{9}$ Pada kasus ini, saat dilakukan anestesi spinal, saat operasi tidak terjadi penurunan tekanan darah yang berarti. Tekanan darah yang turun setelah anestesi spinal biasanya sering terjadi. Hipotensi dapat terjadi pada sepertiga pasien yang menjalani anestesi spinal. ${ }^{10}$ Hipotensi ini dapat terjadi karena penurunan venous return ke jantung, penurunan cardiac output dan penurunan resistensi perifer. Jika terjadi hipotensi, setidaknya terdapat empat alternatif cara pencegahan. Empat cara tersebut adalah pemberian vasopresor, modifikasi teknik regional anestesia, modifikasi posisi dan kompresi tungkai pasien, serta pemberian cairan intravena. ${ }^{11,12}$

Usaha meningkatkan volume cairan sentral dengan pemberian cairan intravena merupakan cara yang mudah dilakukan untuk mencegah hipotensi pada anestesia spinal. Cairan yang diberikan dapat berupa kristaloid atau koloid. ${ }^{13}$ Teknik pemberian cairan dapat dilakukan dengan preloading atau coloading. Preloading adalah pemberian cairan 20 menit sebelum dilakukan anestesia spinal, sedangkan coloading adalah pemberian cairan selama 10 menit saat dilakukan anestesia spinal. Pemberian cairan kristaloid sebagai preloading tidak memperlihatkan manfaat untuk mencegah hipotensi. ${ }^{14,15}$ Pada tindakan-tindakan bedah sesar umumnya dipilih anestesi regional sub arachnoid block/spinal karena mempunyai banyak keuntungan seperti kesederhanaan teknik, onset yang cepat, resiko keracunan sistemik yang kecil, blok anestesi yang baik, pencegahan perubahan fisiologi dan penanggulangannya sudah diketahui dengan baik, analgesia dapat diandalkan, sterilitas dijamin, pengaruh terhadap bayi sangat minimal, dapat mengurangi kemungkinan terjadinya aspirasi, dan ibu dapat kontak langsung dengan bayinya segera setelah melahirkan. ${ }^{16}$ Tetapi anestesi spinal juga bukan tanpa risiko, risiko yang dapat terjadi seperti mual dan muntah bisa terjadi pada anestesi spinal. Bradikardi, disritmia atau bahkan cardiac arrest merupakan komplikasi yang bisa terjadi. ${ }^{17}$

Anestesi spinal terutama yang berdosis tinggi dapat menyebabkan paralisis otot pernafasan, abdominal, intercostal. Oleh karena itu, pasien dapat mengalami kesulitan bernafas. Untuk mencegah hal tersebut, perlu pemberian oksigen yang adekuat dan pengawasan terhadap depresi pernafasan yang mungkin terjadi. ${ }^{18}$ Premedikasi jarang diberikan terutama pada penderita dengan keadaan umum yang buruk, atau karena keterbatasan waktu. Namun pada beberapa kasus dapat diberikan premedikasi secara intravena atau intramuskular dengan antikolinergik disertai pemberian antasida, antagonis reseptor $\mathrm{H} 2$ atau metoclopramide. Pemberian obat anti mual dan muntah sangat diperlukan dalam operasi sectio caesaria emergensi dimana merupakan usaha untuk mencegah adanya aspirasi dari asam lambung. Namun, pada pasien ini tidak diberikan premedikasi. ${ }^{19}$

Induksi menggunakan Bupivacaine $\mathrm{HCL}$ merupakan anestesi lokal golongan amida. Obat anestesi regional bekerja dengan menghilangkan rasa sakit atau sensasi pada daerah tertentu dari tubuh. Cara kerjanya yaitu memblok proses konduksi syaraf perifer jaringan tubuh, bersifat reversibel. Onset kerja lambat jika dibandingkan dengan lidokain. Durasi kerja obat 8 jam. Setelah itu posisi pasien dalam keadaan terlentang (supine). Anestesi spinal mulai dilakukan, posisi pasien duduk tegak dengan kepala menunduk hingga prossesus spinosus mudah teraba. Dicari perpotongan garis yang menghubungkan kedua crista illiaca dengan tulang punggung yaitu antara vertebra lumbal 3-4, lalu ditentukan tempat tusukan pada garis tengah. Kemudian disterilkan tempat tusukan dengan alkohol dan betadin. Jarum spinal nomor 27-gauge ditusukkan dengan arah median, barbutase positif dengan keluarnya LCS (jernih) kemudian dipasang spuit yang berisi obat anestesi dan dimasukkan secara perlahanlahan. ${ }^{20-23}$ Monitor tekanan darah setiap 5 menit sekali untuk mengetahui penurunan tekanan darah yang bermakna. Hipotensi terjadi bila terjadi penurunan tekanan darah sebesar 20-30\% atau sistol kurang dari $100 \mathrm{mmHg}$. Hipotensi merupakan salah satu efek dari pemberian obat anestesi spinal, karena penurunan kerja syaraf simpatis.Bila keadaan ini terjadi maka cairan intravena dicepatkan, bolus ephedrin 5-15 mg 
secara intravena, dan pemberian oksigen. Pada pasien ini terjadi hipotensi. Sesaat setelah bayi lahir dan plasenta diklem diberikan oxytocin 10 IU (1 ampul), diberikan per drip. Pemberian oksitosin bertujuan untuk mencegah perdarahan dengan merangsang kontraksi uterus secara ritmik atau untuk mempertahankan tonus uterus post partum, dengan waktu partus 3-5 menit. Pada pasien ini lahir bayi berjumlah 1. Bayi lahir berjenis kelamin perempuan, lahir pada pukul 12.35 WIB, dengan BB 2700 gram, lahir hidup tanpa kelainan congenital dengan APGAR score 7--8-9. Total perdarahan durante operasi sebanyak $200 \mathrm{cc}$ dan masuk transfusi Packed Red Cell (PRC) 1 kolf setelah operasi berlangsung.

Setelah operasi selesai, pasien dibawa ke HCU Obsgyn. Pasien berbaring dengan posisi kepala lebih tinggi untuk mencegah spinal headache, dikarenakan efek obat anestesi masih ada. Observasi post sectio caesaria dilakukan selama 2 jam, dan dilakukan pemantauan secara ketat meliputi vital sign (tekanan darah, nadi, suhu dan respiratory rate), dan memperhatikan banyaknya darah yang keluar dari jalan lahir. Oksigen tetap diberikan 3 liter/menit. Setelah keadaan umum stabil, maka pasien dibawa ke ruangan bangsal.

\section{Simpulan}

Seorang wanita G3P2A0 36 tahun dengan impending eklampsia, partial HELLP syndrome, hamil preterm, presentasi kepala, belum dalam persalinan pro SCTP-E + MOW dengan status fisik ASA II E Plan RASAB. Dilakukan tindakan sectio caesaria pada tanggal 6 Maret 2016 di kamar operasi IGD atas indikasi impending eklampsia pada preeklampsia berat. Teknik anestesi dengan spinal anestesi (subarachnoid blok) merupakan teknik anestesi sederhana dan cukup efektif. Anestesi dengan menggunakan Bupivakain spinal $10 \mathrm{mg}$, dan untuk maintenance dengan oksigen 3 liter/menit. Perawatan post operatif dilakukan di HCU Obsgyn bangsal Mawar 1 dan dilakukan pengawasan pada tanda-tanda vital serta tanda-tanda perdarahan. Prosedur anestesi spinal pada sectio caesaria dalam kasus ini tidak mengalami hambatan yang berarti baik dari segi anestesi maupun dari tindakan operasinya.
Selama di ruang pemulihan pasien sadar penuh, hemodinamik stabil, dan tidak terjadi hal yang memerlukan penanganan serius.

\section{Daftar Pustaka}

1. American College of Obstetricians and Gynecologists. Hypertension in pregnancy. Report of the American College of Obstetricians and Gynecologists' Task Force on Hypertension in Pregnancy.Obstet Gynecol. 2013;122(5):1122-31.

2. Angsar MD. 'Hipertensi dalam kehamilan', dalam Ilmu Kebidanan Sarwono Prawirodrdjo, edk 4, eds. T Rachimhadhi \& Wiknjosastro GH, Bina Pustaka Sarwono Prawirohardjo: Jakarta. 2009.

3. Butterworth J, Mackey D, Wasnick J. Morgan \& Mikhail's Clinical Anesthesiology, 5e. New York: McGraw-Hill Education. 2013

4. Cunningham, F. G., et al. (2010). Hipertensi dalam kehamilan dalam Obstetri Williams Edisi 21 Volume 2. Jakarta: Penerbit Buku Kedokteran EGC. 2010.

5. Dewi Y. Indikasi Sectio Caesaria. Tingkat Kecemasan suami menghadapi section cesarean pada istri di RSU Sembiring Medan. Skripsi: Medan. 2007

6. Dupont, J. Alima J, Kasia JM, Domgue JF. Maternal and Perinatal Complications of Severe Preeclampsia in Three Referral Hospitals in Yaoundé, Cameroon, (October), 2015, 723-730.

7. Faridz S, Wicaksono B, Dachlan EG, Widjiati. Penurunan progesterone-induced blocking factor sebagai penanda preeclampsia. Majalah Obstetri dan Ginekologi. 2016, 24 : 13-18.

8. Goldenberg R. L, Jones B, Griffin JB, Rouse DJ, Trivedi N, Mcclure E M. Reducing maternal mortality from preeclampsia and eclampsia in low- resource Countries: What 
Should Work? R.L. Obstetric Anesthesia Digest. 2016 36(1).

9. Heazell A, Baker PN. Hypertensive disorders of pregnancy. Oakley C, Warnes CA, eds. Heart disease in pregnancy. 2nd ed. Massachusetts: Blackwell Publishing; 2007, 264-80.

10. Hikmah EV, Maryanto S, Ariesti ND. Hubungan kejadian preeklampsia dengan tindakan sectio caesarea di rumah sakit umum daerah Ambarawa Tahun 2014. Skripsi: STIKES Ngudi Waluyo Ungaran.

11. Kasdu D. Solusi Problem Persalinan. Jakarta: Puspa Swara. 2005

12. Lim KH. Preeclampsia. Beth Israel Deaconess Medical Centre: Israel. 2014

13. Mangku I, Senapati TGA. Ilmu Anestesia dan Reanimasi. Jakarta:Indeks. 2010

14. Mitayani. Asuhan keperawatan maternitas. Salemba medika: Jakarta. 2009

15. Prawirohardjo, Sarwono. Ilmu kebidanan. Jakarta: Yayasan Bina Pustaka. 2005

16. Primatika AD, Marwoto, Sutiyono D. Teknik Anestesi Spinal dan Epiural in Anestesiologi. IDSAI. 2010, 19: 325-30.

17. Ragasudha C, Madhav AP, Sharon S, Priya
SS, Shehnaz S. A study of maternal deaths from preeclampsia and eclampsia in a tertiary care centre. IAIM 2018; 5 (1): 6-10.

18. Sa'adah N. Hubungan Antara Pertambahan Berat Badan Ibu Hamil Dengan Angka Kejadian Preeklampsia Di RSUD Dr. Moewardi Surakarta. Skripsi: Surakarta. 2013

19. Savaj S, Vaziri ND. An overview of recent advances in pathogenesis and diagnosis of preeclampsia. Iran J Kidney Dis. 2012; 6(5):334-8.

20. Shrestha AB, Sharma KR. Spinal anesthesia for cesarean section in preeclampsia. Postgraduated Medical Journal of NAMs. 2012; 12(2), 30-35.

21. Solomon CG, Seely EW. Brief review: Hypertension in pregnancy: A manifestation of the insulin resistance syndrome? Hypertension. 2001; 37:232-9.

22. United Nations. United Nations Millennium Development Goals. http://www.un.org/ millenniumgoals/maternal.shtml- Diakses Maret 2019. 2013

23. WHO. UNFPA, the World Bank, and the United Nations Population Division. Trends in maternal mortality: 1990 to 2013. World Health Organization, 201456; 2014 